\title{
Fimbristylis griffithii (Cyperaceae), a new record for Peninsular India
}

\author{
V.V. Naveen Kumar ${ }^{1}$, V.P. Prasad ${ }^{2 *}$ and C.N. Sunil ${ }^{1}$ \\ 'Post Graduate and Research Department of Botany, S.N.M. College, Maliankara, Ernakulam District, \\ Kerala - 683 516, India. \\ ${ }^{2}$ Central National Herbarium, Botanical Survey of India, P.O. Botanic Garden, Howrah, \\ West Bengal - 711 103, India. \\ *Email: prasad_parur@yahoo.com
}

\section{Abstract}

Fimbristylis griffithii Boeckeler (Cyperaceae) is reported for the first time from Peninsular India. In India, this species was earlier reported only from northeastern state of Assam and the Andaman and Nicobar Islands. A brief description and photo plate are provided for facilitating easy identification.

Keywords: Fimbristylis griffithii, Kerala, New record, Peninsular India.

\section{Introduction}

Fimbristylis Vahl is one of the largest genera of family Cyperaceae comprising c. 316 species (Govaerts et al., 2018) distributed worldwide, especially in the tropics and subtropics. Karthikeyan et al. (1989) enumerated 91 species and Prasad and Singh (2002) reported 115 species from India. Nayar et al. (2006) reported 59 species from Kerala, while Sasidharan (2013) included only 52 species, and Nayar et al. (2014) listed 91 species from the Western Ghats.

During a floristic survey in the forests of Ernakulam district in Kerala, a few interesting specimens of Fimbristylis were collected from the marshy riverbanks in Koomul forest and Kalady plantation. A perusal of the literature and a critical study of the specimens at CAL revealed that they belong to F. griffithii Boeckeler, which is not yet reported from Peninsular India. Hence, its occurrence in Kerala forms a new distributional record for Peninsular India.

\section{Taxonomy}

Fimbristylis griffithii Boeckeler, Flora 43: 241. 1860; J. Kern, Blumea 8: 142. 1955 \& in Steenis, Fl. Males., Ser.1. Spermat. 7: 584. 1974; A.S. Rao \& D.M. Verma, Cyperaceae NE India 34. 1982; Karthik. et al., Fl. Ind. Enum. Monocot. 53. 1989. F. aestivalis var. glaberrima Boeckeler, Linnaea 37: 11. 1871. F. aestivalis sensu C.B. Clarke in Hook.f., Fl. Brit. India 6: 637. 1893, p.p. non (Retz.) Vahl, 1805.

Fig. 1.
Annuals with fibrous roots, glabrous. Culms densely tufted, 8-36 cm long, 1-1.5 mm thick, compressed, 3-5-angled, smooth. Leaves slender, often falcate when young, flat or canaliculate, $7.5-32 \times 0.2-0.45 \mathrm{~cm}$, acute to acuminate at apex, sub-coriaceous, scabrid on involute margins; sheaths 2-3.5 cm long; ligule absent. Inflorescence a decompound corymb, loose, $4.5-10 \times 6-13 \mathrm{~cm}$, bearing 70-90 spikelets. Involucral bracts $4-7$, shorter than inflorescence, scabrid at margins. Primary rays up to $7,2-8 \mathrm{~cm}$ long. Spikelets solitary, angular, oblong-ovoid or ellipsoid, 2.5-4 × 1-1.3 $\mathrm{mm}$, acuteat apex, creamy-greenish, 6-19-flowered, glabrous. Glumes spiral, membranous, elliptic or ovate-lanceolate, 1.3-1.6 × 0.6-1 mm, keeled, with the prominent midvein excurrent into a mucro, with nerveless sides, hyaline towards margins. Stamen 1; filament 1-1.3 mm long, hyaline; anther oblong, $0.3-0.4 \mathrm{~mm}$ long. Ovary obovate; style $0.8-1 \mathrm{~mm}$ long, glabrous; stigmas 2 , c. $0.5 \mathrm{~mm}$ long, ciliate. Achenes biconvex, obovate, $0.5-0.7 \times$ $0.4-0.5 \mathrm{~mm}$, shortly stipitate, smooth; epidermal cells elliptic to rectangular or of different shapes, in 12-15 vertical rows on either face.

Flowering \& fruiting: February-May.

Habitat: Grows in marshy areas at about 130 $\mathrm{m}$ elevation post-monsoon season. It grows in association with Cyperus haspan L. and Fimbristylis aestivalis (Retz.) Vahl. 


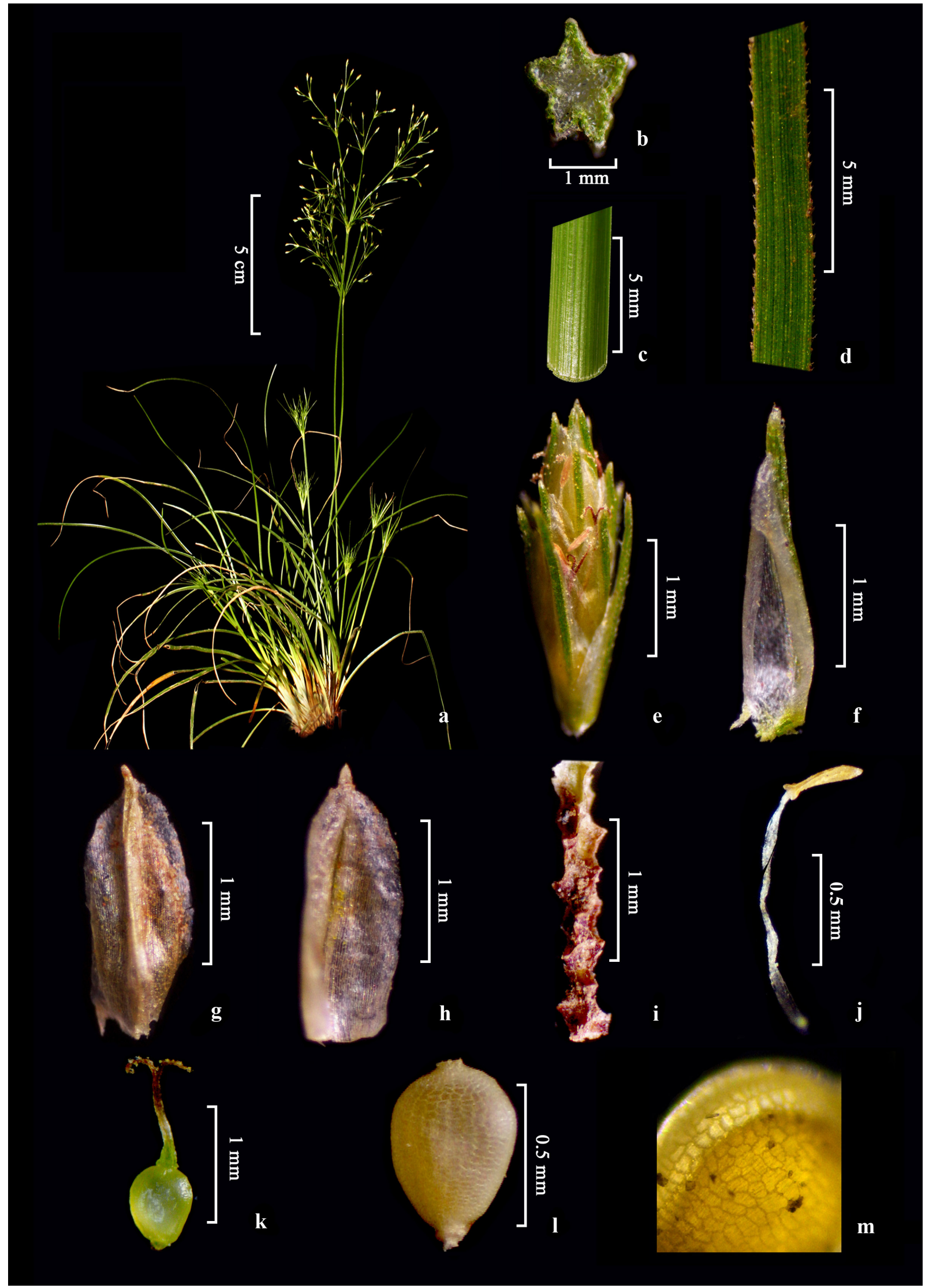

Fig. 1. Fimbristylis griffithii Boeckeler: a. Habit; b. T.S. of culm; c. Leaf blade - lower portion; d. Leaf blade - upper portion; e. Spikelet; f. Glume - lateral view; g. Glume - dorsal view; h. Glume - ventral view; i. Rachilla; j. Stamen; k. Pistil; I. Achene; m. Portion of the achene enlarged. 
Distribution: India (Andaman and Nicobar Islands, Assam and now in Kerala), Malaysia, Myanmar, New Guinea, Thailand and Vietnam.

Specimens examined: INDIA, Kerala, Ernakulam district, Koomul, 13.4.2014, Sunil \& Naveen Kumar 6483 (SNMH); Kalady plantation, 12.2.2017, Sunil E Naveen Kumar 9402 (CAL).

Notes: Fimbristylis griffithii is very similar to F. aestivalis. However, the former can be differentiated by its glabrous culms and style.

\section{Acknowledgements}

The authors are thankful to the Director, Botanical Survey of India, Kolkata and the Head of Office, CAL, Howrah for the facilities. The first author and last author are grateful to the University Grants Commission, New Delhi for the financial assistance and to the Head and staff members of Botany Department, S.N.M. College, Maliankara, Kerala for the facilities. Dr. W. Arisdason, Scientist, Botanical Survey of India, Kolkata, has kindly gone through the manuscript and improved its quality. Thanks are also due to Mr. D.K. Sah, Artist, Botanical Survey of India, Kolkata, for editing the photo plate.

\section{Literature Cited}

Govaerts, R., Koopman, J., Simpson, D.A., Goetghebeur, P., Wilson, K., Egorova, T. \& J.J. Bruhl 2018. World Checklist of Selected Plant Families. Facilitated by the Royal Botanic
Gardens, Kew. Available from: http://apps. kew.org/wcsp/ (accessed 29.09.2018).

Karthikeyan, S., Jain, S.K., Nayar, M.P. \& M. Sanjappa 1989. Florae Indicae Enumeratio: Monocotyledonae. Botanical Survey of India, Kolkata. pp. 50-56.

Nayar, T.S., Sibi, M. \& A.R. Beegam 2014. Flowering Plants of the Western Ghats, India. Vol. 2. Monocots. Jawaharlal Nehru Tropical Botanic Garden and Research Institute, Thiruvananthapuram. pp. 1002-1014.

Nayar, T.S., Beegam, A.R., Mohanan, N., Rajkumar, G. \& M. Sibi 2006. Flowering Plants of Kerala: A Handbook. Jawaharlal Nehru Tropical Botanic Garden and Research Institute, Thiruvananthapuram. pp. 679-687.

Prasad, V.P. \& N.P. Singh 2002. Sedges of Karnataka (India). Scientific Publishers, Jodhpur. p. 151.

Sasidharan, N. 2013. Flowering Plants of Kerala. Ver. 2.0. CD-ROM. Kerala Forest Research Institute, Peechi.

Received on: 21.07.2017

Revised and Accepted: 24.12.2018 